\title{
Payout Policy, Agency Conflict and Corporate Governance in NIGERIA
}

\author{
James O. Odia (PhD) \\ Department Of Accounting \\ University Of Benin \\ Benin City \\ E-mail: odiajames@yahoo.com \\ Phone: 08056580011 \\ Killian Osikhena Ogiedu(PhD)
Department Of Accounting
University Of Benin
Benin City
}

Abstract

This paper investigates payout policy, agency conflicts and corporate governance in Nigeria. Using a sample of thirty (30) listed companies randomly selected in the Nigerian Stock Exchange for the period 2006-2010, the panel OLS regression results indicate that firms' investment opportunities and leverage have significant impact on the dividend payout.The corporate governance mechanisms comprising the CEO shareholdings, directors' shareholdings and the institutional ownership have positive but non-significant impact on the dividend payout.This means that the insiders and institutional ownership may not complete mitigate the agency conflicts associated with effective dividend payout policy. Moreover, the negative and non-significant association of cash-flow and growth of firms may indicate more retentions by directors which may be expropriated by firm's management through salaries and other compensations or invested in projects to satisfy personal benefits at the dispense of the shareholders. Therefore, a strong corporate governance mechanism comprising more non-executive directors and institutional ownership is recommended to mitigate the agency conflicts and improve the dividend payout.

Key words: Payout policy, agency conflicts, corporate governance.

\section{Introduction}

A payout policy involves rules and guidelines of paying proportion of earnings to investors and shareholders as dividend. Agency conflict arises as a result of information asymmetry between stakeholders and management while corporate governance entails legal mechanisms by which the business of the organization are directed and controlled. A payout policy could lead to agency conflict because the financial interest and commitments of agents may sometimes conflict with that of the principal. Normally, the managers of the firm may want earnings to be retained in order to meet firm's needs for growth and takes advantage of emerging investment opportunities while most shareholders or owners will want to receive dividends. In most large publicly traded corporate entities, agency conflicts are quite significant because they play a major role in corporate decisions including the dividend payout (Harada,2006). Shareholders hire individuals with the management expertise to run the corporation on their behalf because they lack the time and expertise to carry out firm's operations and ensure that the corporation provides return for their investment. There is usually agency conflict -a substantially unmitigated 
conflict of interest between the principal and the agent. For instance, managers may have a fundamental objective of maximizing the size of the firm by creating a large rapidly growing firm. They could increase their status, power and salaries, create more job opportunities for lower and middle level managers, as well as enhance their job security. The main objective of corporate governance is how to construct rules and incentives to effectively align the behaviour of managers with the desires of the owners. In fact, managerial ownership, leverage and dividend policies are directly related through agency theories (Jensen,1986). Similarly, ownership structure has been found to help reduce the agency conflict in the dividend payout policies by aligning the interests of owners and management (Leland \& Pyle 1977, Ross, 1977, Easterbrook 1984, Jensen, 1986).

Therefore, the objective of this paper is to examine whether the corporate governance mechanism is able to mitigate the agency conflicts prevalent in the payout policy of quoted companies in Nigeria. The rest of the paper is structured into four sections. The immediate section is the literature review. The next section is the research methodology. The third section is the data analysis and discussions of findings. The summary and conclusion is the last section.

\section{Review of Literature}

Previous studies on dividend policy in Nigeria such as Soyode (1975), Oyejide (1976), Izedonmi \& Eriki (1996), Adelegan (2000), Inanga \& Adelegan (2001) and Adelegan (2003,2007), Musa (2005,2009) have focused attention on the test of Lintner's model. Lintner's (1956) dividend model says that firm targets dividend to permanent or expected earnings and past level of dividend. Izedonmi \& Eriki (1996) examine the payout ratio, dividend per share and earnings per share of 13 quoted companies in Nigerian from 1984-1989.They observe that the Chief Executive Officers (CEO) pay more attention to liquidity and legal provisions in their dividend decisions and that quoted companies do not maintain a target payment ratio. Adelegan (2000, $2002 \& 2003$ ) concludes that dividend policy of quoted firms in Nigeria is influenced by after tax earnings, cash flow, economic policy changes, firm growth potentials and long term debt. Therefore, dividends have information about expected profitability beyond that contained in earnings. Musa (2009) provides evidence that earnings, previous dividend and cash flow all have significant positive impact on the dividend policy of the quoted firms in Nigeria.

\section{Agency conflicts in the agency relations}

The concept of agency theory originated when Berle \& Means (1932) discuss issue of principals and agents and their applications in the development of large corporations. They use the principal- agent relationship to explain the origin of these conflicts. Agency theory is concerned with how the interests of the directors and managers differ from the owners of the firm particularly in relation to dividend payout and retention. Jensen \& Meckling (1976) extend the work of Berle \& Means (1932) in the context of risk-sharing. They assert that corporations are structured to minimize the costs of getting agents to follow the directions and interests of the principal. According to Hawley \& Williams (1996), the agency theory postulates a different perspective of the nature of man as that of seeking self-interest rather than altruistic. Top managers are hired hands who may be more interested in their personal welfare than the shareholders. They may have personal goals which may sometime compete or conflict with the 
maximization of shareholders' wealth. Nevertheless, since the shareholders authorize them to administer the firm's asset, a potential conflict of interest might exist between both parties.

Jensen \& Meckling (1976) affirm the agency problem becomes more evident if both parties are utility maximizers because the agent may not always act in the best interest of the principal. The degree of alignment of interests with those of the agents in the firm who control major decisions in the firm is significant and if ignored, each class of stakeholders pursues its own interest which may be at the expense of the other. Agency theory essentially acknowledges that in an agency relationship, there is bound to be agency conflict. Therefore, the welfare of the principal may not be maximized because the principal and the agent tend to have different goals as well as differing pre-dispositions towards risk (Wright et al, 1996).

Jensen \& Meckling (1976) provide an analysis of the effect of agency conflicts among three groups of insider managers, creditors and shareholders. Their analysis suggests that the proportion of equity controlled by insiders should influence the firm's policies. Managers choose their stock ownership in the firm - the firm's mixture of outside debt and equity financing and dividends to reduce the costs of agency conflicts. Leverage is relevant because using debt reduces the conflict of having outside equity. Managerial ownership and dividend are relevant because they reduce the conflict of interest between managers and outside shareholders (Jensen and Meckling, 1976, Crutchley \& Hansen, 1989, Jensen, Solberg \& Zorn, 1992, Myers, 1977, Smith \& Warner, 1979). Jensen (1986) examines the agency problem of managers investing in negative NPV projects or wasting a firm's earnings when a firm has significant free cash flow. Debt can be effective in reducing this agency cost by bonding management to pay out future cash flows. It also may serve a monitoring function since it subjects management to close review by potential debt holders.

\section{Information asymmetry and the agency conflicts}

Information asymmetry is another important area of conflicting interest between shareholders and managers. According to Pandey (2005), managers may not share complete information with the shareholders and this creates a gap between information available and what is actually shared with the shareholders. This problem of information asymmetry may manifest itself in numerous ways such as direct wealth transfer from financiers to managers, sub-optimal allocation of capital and management prerequisite compensation. Leland \& Pyle (1977) and Ross (1977) present hypotheses that insider ownership and financial policies help to resolve informational asymmetry between managers and external investors.

\section{Dividend policy and agency conflicts}

Dividend policy may be one indicator of conflicts of interest between minority investors, owners and managers. Agency problems may lead to overinvestment, excess resource consumption of various kinds and inflated salaries by managers. It is possible for smart insiders to keep dividend high as a visible signal of good faith to the minority investors while they behave more selfishly in other respects. With respect to common stock investment, shareholders' interest is simply to increase the value of their shares by receiving high dividends. But the managers are interested in 
high retentions so as to engage in continued growth of the company as well as to satisfy other stakeholders thereby indirectly providing personal benefits to them.

One of the biggest conflicts of interest between shareholders and managers is usually in the payout policy in companies. However, payout can be used to self-impose discipline. Easterbrook (1984), Jensen (1986) have suggested that equity-holders can minimize the cash that management controls and thereby reduce their opportunity to go on (unmonitored) spending sprees or investing in negative NPV projects. They argue that one way to remove surplus cash from the firm is to increase payout. The payment of dividends has been proposed as useful in minimizing manager-shareholder agency conflicts. Moreover, dividend payout has been viewed as containing both bonding and monitoring characteristics (Easterbrook 1984, Rozeff,1982).As bonding mechanism, dividend policy will not only decrease agency cost of equity, reduce the opportunity for managers to use firm cash flow for perquisites activities but also decrease their ability to pursue new investment opportunities (Megginson, 1997: 377) .

According to the signalling theory, dividend can mitigate information asymmetries between managers and shareholders by conveying inside information of a firm's future prospects. The Agency theory argues that dividend reduces the costs of shareholder-manager conflict and it performs a controlling function where monitoring of firm's management by its shareholders is inactive (Rozeff, 1982; Easterbrook, 1984; Jensen, 1986). Jensen (1986) argues that by paying dividend the discretionary resources under managerial control can be decreased and in this way the over-investment problem can be resolved.

\section{Factors affecting dividend payout policy}

Corporate decisions that border on payout policy are function of many factors such as: Legal constraint, earnings cash flow and liquidity, shareholders expectation, availability of profitable investment opportunities, shareholders tax bracket, management control and contractual constraints. Other factors include: business cycles, government policies, attitude of management, shareholders' income needs, age of the corporation, stability in dividend payment over time (Keown et al 1996, Brigham \& Houston 2004, Pandey 2005, Aregbeyen,2005). Firm characteristics also influence dividend policy (Aivazian, Booth \& Cleary, 2003, Allen \& Michaely, 2002). Dividend payouts are found to be negatively related to profitability and leverage, but positively related to asset tangibility and market-to book. Pecking order theory suggests that profitable firms in determining financing choices will seek to retain free cash flow and hence lower dividend payments (Myers \& Majluf, 1984). It follows that dividend payout is inversely related to the firm's profitability. Ramli (2010) finds that size of the company and profitability level are positively and statistically significantly related to dividend ratio. These results agree with Fama \& French (2001) and Truong \& Heaney (2007). However, investment opportunities of Malaysian companies (INV) have no significant influence on the level of companies' dividend payout.

Capital structure choice models suggest that more long-term debt is used as the tangibility of the firm's assets increases and as more collateral accumulates, increasing firm leverage reduces free cash flow thereby implying lower dividend payouts. Adelegan (2002) finds that the pecking 
order is applicable to financing decisions and dividend payouts of large firms in Nigeria. Both leverage increases and dividend payments reduce free cash flow, hence, leverage is inversely related to dividend payments. DeAngelo et al (2009) conclude that managerial signaling motives, clientele demands, tax deferral benefits, investors' behavioral heuristics and investor sentiment have at best minor influences on payout policy but behavioral biases at the managerial level (e.g. over-confidence) and the idiosyncratic preferences of controlling stockholders plausibly have a first-order impact on the payout policy.

\section{Corporate governance, ownership structure and dividend payout policies}

Jensen,Solberg \& Zorn (1992) identify an inter-relationship between levels of insider ownership, leverage and dividend payout, with insider ownership negatively impacting on debt and dividend levels. This suggests that insider ownership and financing policy (leverage and dividend payout) are substitute mechanisms in potentially reducing agency costs. Similarly, Moh'd, Perry \& Rimbey (1995) find that insider ownership and leverage negatively impact on dividend payout ratios and that higher institutional investment significantly increases payout ratios, suggesting that firm's dividend policy is determined in a manner consistent with minimizing agency-related costs. Agrawal \& Knoeber (1996) provide evidence of inter-relationships between alternative agency mechanisms including leverage, insider ownership, institutional ownership, existence of blockholders and takeover market activity. Crutchley, Jensen, Jahera Jr. \& Raymond (1999) provide evidence of simultaneity between various agency-control mechanisms and support for institutional ownership substituting for other attributes mitigating agency costs. Jensen \& Meckling (1976) and Leland \& Pyle (1977) posit that higher levels of equity ownership by insiders in a firm encourage the pursuit of objectives that maximize shareholder wealth. Therefore, the use of managerial compensation plans that include or are directly tied to the firm's stock has been proposed to better align management and shareholders' interests (Jensen \& Meckling 1976, Smith \& Watts 1982, Jensen \& Murphy 1990). Since institutional owners often own relatively large blocks of common stock, they should have a significant incentive to act as a monitor and question behavior that reduces share value. Shleifer \& Vishny (1986) note that this incentive exists for large shareholders since the benefits from the monitoring actions exceed their costs. Block-holder ownership is found to have a negative effect on pay-out ratios. Nevertheless the level of block-holder ownership may influence stock market reactions to changes in dividends and the dividend policy may influence stock market reactions to changes in blockholder ownership.

Grinstein \& Michaely (2004) find no relationship between the level of dividends and the extent of the institutional holdings. Firms tend to increase dividend when they become more mature and less risky as well as with the "bird in the hand" argument. Miller \& Rock (1985) argue that the cost of dividends is that "good" firms shave investment to pay the dividend (and only good firms will find it valuable enough to do so). Fenn \& Liang (2001) and Weisbenner (2000) report a negative relationship between stock option plans and dividends and argue that this is consistent with the notion that managerial incentive plans reduce managers' incentive to pay dividends because executive options are not dividend protected. Kumar (2006) finds for a panel of Indian firms for 1994-2000 that ownership by corporation and directors, investment opportunities and 
earnings are positively related with dividend while leverage and square of corporation ownership are negatively related with dividend. Moreover, Afza \& Mirza (2010) find for 100 KSE listed companies that managerial and individual ownership, cash flow sensitivity, size and leverage have negative relation while operating cash flow and profitability are positively related to cash dividend.

The relationship between ownership structure and dividend policy has been emphasized by La Porta, Silanes, Shleifer \& Vishny, (2000), Gugler \& Yurtoglu, (2003), Da Silva, Goergen \& Renneboog, (2004). La Porta et al. (2000) find that stronger minority investor rights are associated with higher dividend payouts which they interpret to indicate that minority shareholders pressure corporate insiders to pay out dividends. Gugler \& Yurtoglu (2003) find large negative effects of announced dividend changes in German companies where corporate insiders have more power. Da Silva et al (2004) find a U-shaped relationship such that dividends first decrease and then increase with the voting share of the largest owner. In principle, controlling owners will prefer to retain profits as long as their private benefits per unit of retained earnings exceeds their share of the after tax dividend. Ramli (2010) finds that Malaysian companies make higher dividend payout as the shareholdings of the largest shareholder increase and the presence of substantial second largest shareholder in the company result in larger dividend payout.

Based on the literature review, the following hypotheses are formulated

1. There is significant association between dividend payout and the cash flow;

2. There is significant association between dividend payout and insider's ownership;

3. There is significant association between dividend payout and institutional ownership; and

4. There is significant association between dividend payout and leverage.

5. There is significant association between dividend payout and investment opportunities.

\section{Method}

The sample size comprises thirty (30) quoted companies in Nigerian Stock Exchange selected by simple random sampling from 2006 to 2010. The data was collected from the companies' annual financial reports and the Fact-Book of the Nigerian Stock Exchange for the period under consideration. Correlation and regression analyses were employed for the study.

\section{Model Specification}

The model is based on the model developed by Kose \& Anzhele (2006).It is specified as: DIVP = f (SIZE, DSAL, DSHD, LEV, R\&D CASHFLOW, GROWTH, INV.OPP, TAXES, CEOOWN, INSTOWN) In econometric form, this becomes:

DIVP $=\beta_{0}+\beta_{1}$ SIZE $+\beta_{2}$ DSAL $+\beta_{3}$ LEV $+\beta_{4}$ R\&D $+\beta_{5}$ CASHFLOW $+\beta_{6}$ GROWTH $+\beta_{7}$ INVOPP + B ${ }_{8}$ TAXES $+\beta_{9}$ CEO OWN $+\beta_{10}$ INSTOWN $+\beta_{11}$ DSHD

The measurement of the dependent and independent variables adapted from Kose \& Anzhele (2006) is shown in table 1 below.

Table 1 Measurement of variables 


\begin{tabular}{|l|l|l|l|l|}
\hline S/No & Variables & Proxies & Measurement & Expected sign \\
\hline 1. & Dividend payout & DIVP & Total dividend/Total assets & - \\
\hline 2. & Firm size & SIZE & Logarithms of Total assets & + \\
\hline 3. & Directors' shareholdings & DSHD & Total Board of Directors Shares / Total Shares & + \\
\hline 4. & Director's salary \& compensation & DSAL & $\begin{array}{l}\text { Total Directors' Salary \& compensation / Total Salary \& } \\
\text { Compensation. }\end{array}$ & - \\
\hline 5. & Leverage & LEV & Total debts (Current \& Long term liability) / Total assets & - \\
\hline 6. & Research \& development & R\&D & Total amount on R\&D / Sales & - \\
\hline 7. & Cash flow & CASHFLOW & $\begin{array}{l}\text { Earnings before interest , taxes \& depreciation /Total assets } \\
\text { EBITDA/TA) }\end{array}$ & + \\
\hline 8. & Growth of company's sales & GROWTH & $\begin{array}{l}\text { Sales in current year less Sales in previous year/ Sales in } \\
\text { current year [Sales (yr1) }- \text { Sales (yr0)/ Sales (yr1) ] }\end{array}$ & + \\
\hline 9. & Investment opportunity & INVOPP & Capital Expenditure (Total fixed assets) /Total assets & - \\
\hline 10 & Total taxes paid & TAXES & Taxes/Earnings before Interest \& Taxes (EBIT) & - \\
\hline 11. & CEO ownership & CEO OWN & Shares own by Chief Executive Officer/Total Shares. & + \\
\hline 12 & Institutional ownership & INSTOWN & Shareholdings of institutional owners/ total shares & + +- \\
\hline
\end{tabular}

Source: Adapted from Kose \& Anzhele (2006)

The insider ownership is captured by directors' shareholdings and chief executive officer ownership. The salary and other non-stock compensation of directors basically indicate the conflicts between the owners and management. The inclusion of leverage and managerial ownership (CEO and directors' shareholdings) is to mitigate the information asymmetry and agency conflicts. Institutional owners help in the monitoring and mitigation of the agency costs. They could facilitate increase payout. The firm size, cash flow, growth, investment opportunity are control variables. Rozeff (1982) finds a negative relationship between inside shareholders and dividend payout, while a positive relationship was found between dispersed shareholding and dividend payout. Jensen et al (1992) find insider ownership as an important determinant of a firm's dividend policy and debt. They find that investment and growth were related negatively to dividend, while profitability was found positively associated with dividend Afzal \& Sehrish (nd) investigate the impact of ownership structure and board composition on corporate dividend policy (payment and decisions) of 42 non-financial listed firms in Karachi Stock Exchange (KSE) in Pakistan from 2005 to 2009. They find board size, individual ownership, firm size and investment opportunities are positively and significantly associated with the amount of dividend paid. On the other hand, insider ownership and firm's profitability show significantly negative impact on dividend payment. Institutional ownership and leverage have a negative and insignificant effect while board independence is positively and insignificantly with the payout ratio. In relation to dividend decision, individual ownership and insider ownership are negative while profitability is positively and significantly related. Investment opportunities are found to be positively but insignificantly related with dividend decisions.

\section{Data analysis}

The descriptive statistics is depicted in table 2 below.

Table 2 Descriptive statistics for the panel data

\begin{tabular}{|l|l|l|l|l|}
\hline Variables & Mean & Standard deviation & Minimum & Maximum \\
\hline DIVP & 4.856 & 3.47 & 1.71 & 13.89 \\
\hline
\end{tabular}




\begin{tabular}{|l|l|l|l|l|}
\hline CASHFLOW & 12.33 & 9.23 & 3.63 & 48.83 \\
\hline GRT & 51.32 & 22.72 & -7.80 & 101.50 \\
\hline INVOPP & 153.26 & 32.08 & 106.3 & 223.70 \\
\hline SIZE & 52.67 & 4.82 & 45.78 & 62.32 \\
\hline R\&D & 71.17 & 36.16 & 27.01 & 151.07 \\
\hline LEV & 8.54 & 24.71 & 165.70 & 361.03 \\
\hline CEOSHARE & 38.40 & 10.53 & 22.02 & 63.55 \\
\hline DSAL & 0.45 & 0.46 & 0.173 & 2.84 \\
\hline DSHD & 63.61 & 10.36 & 35.34 & 80.98 \\
\hline INSTOWN & 482.64 & 1014.68 & 164.85 & 5848 \\
\hline TAXES & 159.16 & 20.90 & 261.40 \\
\hline
\end{tabular}

Source: Author's computation

From table 2, dividend payout was between $1.71 \mathrm{k}$ and N13.89 or an average of $4.856 \mathrm{k}$ over the period. The sales and capital expenditures grew by an average of $51.37 \%$ and $153.26 \%$ respectively. Similarly, there was increase in the corporate taxes by about $159.16 \%$ and cash flows directors' salaries and compensations increased on the average by $12.33 \%$ and $0.45 \%$ respectively. The CEO and directors' shareholdings hover between the average of $38.40 \%$ and $63.41 \%$ respectively for the period.

The Pearson correlation result in table 3 indicates the there is a significant relationship between the payout and the cash flow, growth, investment opportunity (proxied by the capital expenditure) and leverage. However, the CEO, directors (insider) and institutional ownerships are not correlated with the payout policy of firms. The investment opportunities tend to have the greatest correlation with the payout decision. This indicates that less investment in capital expenditure may lead to increase in the dividend payout. Moreover, the increase in the growth of the firm's sales or earnings and excess cash are related to the payout of firms. The directors' salary and compensation is negatively related to the payout policy.

Table 3 . Pearson Correlation

\begin{tabular}{|c|c|c|c|c|c|c|c|c|c|c|c|c|}
\hline Variable & DIVP & CFLOW & GRT & INVOPP & SIZE & R\&D & LEV & $\begin{array}{l}\text { CEO } \\
\text { OWN }\end{array}$ & DSAL & DINT & INSTOWN & TAXES \\
\hline DIVP & 1.000 & & & & & & & & & & & \\
\hline CASHFLOW & $0.385^{* *}$ & 1.000 & & & & & & & & & & \\
\hline GRT & $0.391 * *$ & 0.185 & 1.000 & & & & & & & & & \\
\hline INVOPP & $0.785^{* * *}$ & $0.451 * *$ & $0.460 * *$ & 1.000 & & & & & & & & \\
\hline SIZE & 0.334 & 0.026 & -0.133 & $0.392 * *$ & 1.000 & & & & & & & \\
\hline R\&D & 0.031 & 0.155 & 0.310 & -0.026 & $\overline{-}-687 * * *$ & 1.000 & & & & & & \\
\hline LEV & $0.375^{* * *}$ & 0.209 & 0.243 & 0.078 & -0.176 & 0.129 & 1.000 & & & & & \\
\hline CEOOWN & 0.212 & -0.149 . & $0.432 * *$ & 0.352 & 0.189 & -0.013 . & 0.253 & 1.000 & & & & \\
\hline DSAL & -0.015 & -0.122 & 0.091 & -0.079 & -0.116 & -0.169 & 0.016 & 0.105 & 1.000 & & & \\
\hline DSH & 0.085 & 0.037 & -0.072 & 0,256 & 0.179 & 0.014 & 0.089 & 0.440 & -0.131 & 1.000 & & \\
\hline INSTOWN & -0.147 & -0.109 & -0.046 & -0.076 & -0.065 & -0.102 & -0.053 & 0.081 & -0.034 & -0.042 & 1.000 & \\
\hline TAXES & 0.237 & 0.145 & 0.205 & 0.205 & 0.017 & 0.204 & -0.007 & $0.362^{*}$ & 0.134 & 0.267 & -0.165 & 1.000 \\
\hline
\end{tabular}

\section{Discussion of regression results}

The regression results are shown in table 4. The cross-sectional results indicate that the cash flow, investment opportunity, CEO shareholdings, growth of firm's earnings, leverage and firm size have significant impact on the firm's payout policy. The cash flow has significant impact on the dividend payout in 2006 and 2010.This supports the findings of Adelegan (2000,2002 \& 2003) and Musa (2009) that the cash flow influences the dividend policy in Nigeria. Afza \& Mirza (2010) find that operating cash flow and profitability of the firm are significantly and positively with dividend payout. The finding also confirms the bird-in hand argument that 
investors are generally risk averse and would rather have dividends today in the form of cash than a probable share appreciation which comes with uncertainty. When a firm has investment opportunities, they may not want to pay dividend so as to invest on the available opportunities. When a company has more profitable investment opportunities available and high equity/debt ratio, it has the tendency to follow a policy of high retention ratio and low payout ratio. However, the panel regression result indicates that increase in investment opportunities do not decrease dividend payouts as Investment opportunity has significant and positive association with the dividend payout. This result disagrees with Jensen et al (1992) which found a negative relation. The CEO shareholding has significant association with the dividend payout in 2008. In other words, where the CEOs have substantial shareholdings in the firms, they could exhibit much influence in the dividend payout policy. However, the directors' shareholdings do not seem to have significant association with the dividend payout. Although directors' shareholdings in the company might lead to maximization of the shareholders' wealth, it has no significant association with the dividend payout. This result partly supports Jensen \& Meckling (1976) and Leland \& Pyle (1977) that a higher level of equity ownership by insiders in a firm encourages the maximization of shareholder's wealth. The firm size and expenditure on research and development have significant impact on the payout policy in 2008.

Table 4 Regression Results (Dependent variable: DIVP)

\begin{tabular}{|c|c|c|c|c|c|c|}
\hline $\begin{array}{l}\text { Independent } \\
\text { variables }\end{array}$ & 2006 & 2007 & 2008 & 2009 & 2010 & $\begin{array}{l}2006-2010 \\
\text { (Pooled data) }\end{array}$ \\
\hline Constant & -0.308 & -1.777 & $-2.778 * *$ & -1.400 & -2.231 & $-15.173^{*}$ \\
\hline CASHFLOW & $0.787 * * *$ & 0.171 & 0.222 & 0.049 & $0.108^{*}$ & -0.12 \\
\hline GRT & $-0.057 *$ & 0.003 & 0.056 & 0.009 & -0.010 & -0.16 \\
\hline INVOPP & 0.010 & 0.020 & 0.010 & 0.041 & $0.042 *$ & $0.078 * * *$ \\
\hline SIZE & 0.029 & 0.094 & $0.251 *$ & -0.006 & 0.179 & 0.162 \\
\hline R\&D & -0.049 & -0.288 & $0.027 * *$ & 2.383 & -0.012 & 0.016 \\
\hline LEV & 0.001 & $0.000 * * *$ & 0.012 & 0.005 & 0.003 & $0.001 * *$ \\
\hline CEOSHARE & 0.065 & 0.053 & $0.000 * * *$ & 0.058 & 0.029 & 0.018 \\
\hline DSAL & 1.648 & -0.106 & 0.359 & -1.484 & 0.461 & 0.370 \\
\hline DSHD & 0.582 & 0.229 & 0.197 & -0.004 & 0.716 & 0.041 \\
\hline INSTOWN & 0.012 & 0.003 & -1.991 & 0.010 & 0.018 & 0.000 \\
\hline TAXES & 0.010 & 0.002 & -0.017 & -0.008 & -0.010 & 0.006 \\
\hline $\mathrm{R}^{2}$ & 0.733 & 0.845 & 0.837 & 0.410 & 0.506 & 0.764 \\
\hline $\mathrm{R}^{-2}$ & 0.569 & 0.751 & 0.738 & 0.049 & 0.203 & 0.619 \\
\hline $\mathrm{F}$ & $4.486^{* * *}$ & $8.935^{* * *}$ & $8.413 * * *$ & 1.137 & 1.673 & $5.289 * * *$ \\
\hline DW & 2.267 & 1.767 & 2.780 & 1.824 & 2.373 & 2.378 \\
\hline
\end{tabular}

From table 4, growth of the firm sales has significant but negative association with the dividend payout policy of the firm in 2006. This indicates that when a firm's sales or earnings grow, the increase cash flow or return on earnings may not result in increased dividend payout .Taxes has negative and non-significant impact on the dividend from 2008 tom 2010. In other word, it is expected that as the corporate taxes increase the dividend payout will decrease unless the firm maintains a stable payout policy. The regression results in 2009 shows that none of the variables have significant impact on the dividend payout. The cash flows and investment opportunities have significant association with the dividend payout in 2010.The salaries and other compensations of directors has negative and non significant association with the dividend payout in 2007 and 2009. 
The OLS regression result for the panel data shows that the investment opportunities and leverage have significant association with the dividend payout. This indicates that directors may recommend increase in dividend payout to justify their increase investment in capital expenditures to the shareholders. The insiders' ownership comprising CEO and directors' shareholdings, and institutional ownership have positive and non-significant association with the dividend payout. This result does not support the negative relation found by Rozeff (1982) and Jensen et al (1992) the cash flow and growth of firm's sales have negative and non-significant association with the dividend payout. Contrary to our expectation, the result indicates that as the investment opportunities and the leverage increase, the dividend payout also increases. Again the insider's and institutional investors' ownership do not have major influence on the dividend payout indicating that the insiders may directly or indirectly be more interested in other benefits, compensations and remuneration than the dividends. In fact, the negative and non-significant association of cash flow and growth of firm's sales/earnings with the dividend payout indicates that the excess cash and growth of the firm's sales do not result in increased dividend payout. This could mean that firm's management and directors may retain excess cash in other to expropriate them for their personal benefits (Jensen,1986.,Shleifer \& Vishny,1997). The salaries and other compensations of directors has no significant association with the dividend payout

\section{Summary and Conclusion}

The paper examines the dividend payout policy, agency conflict and corporate governance of listed companies in Nigeria. Basically, the dividend payout results in agency conflict which occurs as a result of information asymmetry between management and shareholders or owners since the owners may want dividends but the management will want to retain the surplus to take advantage of the available investment opportunities. The corporate governance is expected to help to prevent or minimize this agency conflicts. The findings from the study include:

1. The investment opportunities and leverage has positive and significant association with the dividend payout.

2. The insider's ownership (CEO shareholdings and directors' shareholdings) and institutional ownership have positive and non-significant association with the dividend payout.

3. The cash flow and growth of firm's sales has negative and non-significant association with the dividend payout.

The following recommendations are suggested to mitigate the agency conflicts between the shareholders and directors with respect to the dividend payout policy. First, firms should maintain reasonable leverage since debts can be effective in reducing this agency cost by bonding and monitoring management to pay out future cash flows. Second, the board should compose of non-executive and institutional investors to help mitigate the agency conflicts associated with the dividend payout. Third, the corporate governance mechanism should be strengthened to monitor the activities of the board which conflict with the shareholders interests by reducing the information gap

\section{References}


Adelegan, O. J. (2002): The pecking order hypothesis and corporate dividend payout: Nigerian evidence. African Review of Money Finance and Banking, 75-93

Adelegan, O.J. (2003): An empirical analysis of the relationship between cash flow and dividend changes in Nigeria. African Development Review, 15(1), 35-49.

Afza, T. \& Mirza, H.H.(2010). Ownership structure and cash flows as determinants of corporate dividend policy in Pakistan. International Business Research,3(3),210-221.

Afzal,M \& Sehrish,S (nd). Ownership Structure, Board Composition and Dividend Policy in Pakistan.Working paper, COMSATS Institute of Information Technology, Islamabad Pakistan

Agrawal, A. \& Knoeber, C.R. (1996). Firm performance and mechanisms to control agency problems between managers and shareholders. Journal of Financial and Quantitative Analysis 31, 377-397.

Aivazian, V., Booth, L \& Cleary, S. (2003). Do emerging market firms follow different dividend policies than firms in the U.S: Evidence from 8 emerging markets. Journal of Financial Research, 26,371-387.

Allen, F. \& Michaely, R (2002). Payout policy in Constantinides, G., Harris,M. and Stulz,R. ed. Handbooks of Economics, North-Holland, Amsterdam.

Aregbeyen, O. (2005). The determinants of firm's dividend payments in Nigeria. International Journal of Business and Common Market Studies,3(1),35-43.

Berle, A. A. \& Means, G.C. (1932). The modern corporation and private property. New York, Macmillan.

Brigham, E. F. \& Houston, J. F. (2004). Fundamentals of financial management. USA: SouthWestern Publishers.

Crutchley,C.E, \& Hansen,R.S.(1989). A test of the agency theory of managerial ownership, corporate leverage and corporate dividends. Financial Management, 36-46.

Crutchley, C.E., Jensen, M.R.H., Jahera Jr, J.S. \& Raymond, J.E. (1999). Agency problems and the simultaneity of financial decision making: The role of institutional ownership. International Review of Financial Analysis 8, 177-197.

Da Silva, L. Goergen, M. \& Renneboog, L. (2004). Dividend policy and corporate governance. Oxford University Press.Oxford.

DeAngelo,H., DeAngelo, L \& Skinner ,D.J (2009) . Corporate payout policy. Working paper University of Southern California and University of Chicago Booth School of Business

Fama, E.F.(1980). Agency problems and the theory of the firm. Journal of Political Economy, 88, 134-145 
Fama, E. F. \& French, K. R. (2001). Disappearing dividends: Changing firm characteristics or lower propensity to pay? Journal of Financial Economics, 60,3-43

Gugler, K. \& Yurtoglu, B.( 2003). Corporate governance and dividend pay-out policy in Germany. European Economic Review (47),731-758.

Harada, K. (2006). Ownership concentration, agency conflict and dividend in Japan. Journal of Economics and Law.

Harris, M.\& Raviv, A.( 1991). The theory of capital structure. Journal of Finance, 46 297-355.

Hawley J.P. \& Williams, A. J.(1996). Corporate governance in the United States: The rise of all fiduciary capitalism. Paper presented at Saint Mary's College of California School of Economics and Business Administration.

Inanga, E.L (1975). Dividend policy in an era of indigenization: A comment. Nigerian Journal of Economics and Social Studies, 17(7),111.

Izedonmi, F.I.O. \& Eriki, P.O. (1996).Determinants of dividend policy in publicly quoted companies. ICAN News, 15-19 October/December

Jensen, M. \& Meckling, W. H. ( 1976). Theory of the firm: managerial behaviour, agency costs and ownership structure. Journal of Financial Economics, 3 305-360.

Jensen, M., (1986). Agency costs of free cash flow, corporate finance and takeovers. American Economic Review, 76 ,323-329.

Jensen, G.R., D.P. Solberg, D.P. \& Zorn, T.S. (1992). Simultaneous determination of insider ownership, debt and dividend policies, Journal of Financial and Quantitative Analysis 27, 247-263.

Jensen, M,C. \& Kevin J.M (1990).Performance pay and top-management incentives," Journal of Political Economy,98,225-264.

Kose, J. \& Anzhele,K (2006). Payout policy , agency conflicts and corporate governance. Working paper New York University

Kumar, J. (2006). Corporate governance and dividend policy in India. Journal of Emerging Market Finance,5(5), 15-58.

La Porta, R., Lopez de Silanes, F., Shleifer, A., \& Vishny, R. W. (2000). Agency problems and dividend policies around the world. Journal of Finance, 55(1), 1-33

Leland, M. \& Pyle,D.(1977). Informational asymmetries, financial structure and financial intermediation. Journal of Finance, 32,371-387

Lintner, J. (1956) Distribution of incomes of corporations among dividends, retained earnings and taxes. American Economic Review, 46 97-113.

Megginson, W.L. (1997). Corporate finance theory, Addison-Wesley. 
Miller, M.H. \& Modigliani, F. (1961). Dividend policy growth and the valuation of shares. Journal of Business, 34 411-433

Moh'd, M.A., Perry,L.G. \& Rimbey, J.N. ( 1995). An investigation of the dynamic relationship between agency theory and dividend policy. Financial Review 30, 367-385.

Musa, F.I (2005).Modelling the dividend behavioural pattern of corporate firms in Nigeria. Unpublished doctoral dissertation, Ahmadu Bello University, Zaria pp 85 - 152.

Musa, F.I. (2009). The dividend policy of firms quoted on the Nigerian stock exchange: An empirical analysis. African Journal of Business Management,3(10),555-566, October

Myers, S.C \& Majluf, N. S. (1984). Corporate financing and investment decisions when firms have information investors do not have. Journal of Financial Economics, 13,187-222

Oyejide, T.A. (1976).Company dividend policy in Nigeria: An empirical analysis. Nigerian Journal of Economics and Social Studies, 18(2):179.

Ramli,N.M. (2010). Ownership Structure and dividend policy: Evidence from Malaysian companies. International Review of Business Research Papers 6(1), 170-180 February

Ross,S.A.(1977).The determination of financial structure: The incentive-signaling approach. Bell Journal of Economics, 23-40.

Rozeff, M. (1982). Growth, beta and agency costs as determinants of dividend payout ratios. Journal of Financial Research, 5,249-259

Soyode, A. (1975). Dividend policy in an era of indigenization: A comment. Nigerian Journal of Economics and Social Studies, S17(8), 126.

Shleifer, A \& Vishny, R. W. (1986). Large shareholders and corporate control. Journal of Political Economy, 94, 461-488.

Shleifer A. \& Vishny, R. (1997).A survey of corporate governance. The Journal of Finance, 52:737-83.

Smith, C.W. \& Watts,R.L (1982).Incentive and tax effects of U.S. compensation plans. Australian Journal of Management 7,139-157.

Truong, T \& Heaney, R. (2007). Largest shareholder and dividend policy around the world.The Quarterly Review of Economics and Finance 47(5):667-687.

Uzoaga, W.O \& Alozieuwa, J.U. (1974).Dividend policy in an era of indigenization. Nigerian Journal of Economics and Social Studies, 16(11), 461.

Appendix : Sampled companies

\begin{tabular}{|l|l|}
\hline 1 & Intercontinental Bank \\
\hline 2 & GT Bank \\
\hline 3 & Sterling Bank \\
\hline
\end{tabular}




\begin{tabular}{|l|l|}
\hline 4 & Zenith Bank \\
\hline 5 & First Bank \\
\hline 6 & Eco Bank \\
\hline 7 & Wema Bank \\
\hline 8 & Access Bank \\
\hline 9 & First City Monument Bank \\
\hline 10 & Union Bank \\
\hline 11 & Nigeria Breweries \\
\hline 12 & Guinness \\
\hline 13 & Leventis \\
\hline 14 & May \& Baker Nig Plc \\
\hline 15 & Total Oil Plc \\
\hline 16 & Nigerian Bottling Company \\
\hline 17 & Dangote Sugar Plc \\
\hline 18 & Vitafoam Plc \\
\hline 19 & Julius Berger Plc \\
\hline 20 & Flour Mill of Nig Plc \\
\hline 21 & UAC \\
\hline 22 & Honeywell Flour Mill Plc \\
\hline 23 & Nigerian Ropes Plc \\
\hline 24 & Mobil Oil Nig Plc \\
\hline 25 & UTC \\
\hline 26 & Lafarge Cement Wapco Nig Plc \\
\hline 27 & Nestle Plc \\
\hline 28 & Chellarams \\
\hline 29 & JohnHolt \\
\hline 30 & Neimeth Int Pharmacetical \\
\hline & \\
\hline
\end{tabular}

